\title{
Perceptions of Neust Instructors, Deans and Directors toward Leadership Capabilities
}

\author{
Kim Edward S. Santos, MBA; Merlina C. Garcia, MaEd, LPT
}

${ }^{1} \mathrm{Ph}$. DBA Candidate in Wesleyan University-Philippines, Instructor, College of Management of Business and Technology, Atate Campus, Nueva Ecija University of Science and Technology, Nueva Ecija, Philippines

kimnyte@gmail.com/kesantos@ neust.edu.ph

${ }^{2}$ Assistant Professor, Atate Campus, Nueva Ecija University of Science and Technology, Linguistics and Literature Department, College of Management and Business Technology, College of Information and Communications Technology

merlina.garcia@yahoo.com

\begin{abstract}
Leadership has the power to create, sustain, and destroy an organization. It is the key to effective management. The study described the perceptions of NEUST Campus Directors, College Deans and instructors towards their leadership capabilities in terms of job knowledge and managements skills, language communication, cultural and professional growth and personal and social qualities, and differences between NEUST Campuses directors' / deans' and instructors' perceptions. The descriptive method of research was used in this study. A total of 103 respondents composing of 15 academic deans/directors and 88 college faculty in the 5 campuses of NEUST were surveyed. Mean, Weighted Mean and Standard deviation were used to analyze the gathered data. Based on the foregoing findings, the following conclusions were drawn: First, academic deans/directors have high regard among themselves to be outstanding in their leadership capabilities. This implies that they were confident enough in their leadership capabilities. Second, instructors perceived their deans/directors to be human relations oriented. They cultivated the values of openness, fairness and approachability. Instructors feel comfortable with the "selfassurance" that their administrators were very much concerned of their welfare, personally and professionally. And last, there was incompatibility between deans'/directors self-perception and instructors' perception in the formers leadership capabilities. There were differences in the ratings of the two groups. Deans/Directors rated themselves good performers. The difference, though, is spatial rather than dimensional. In other words, the qualities that leaders possessed were perceived by both deans and instructors along a similar scale, although the measures varied. In lieu of the stated conclusions, the researchers came up with the following recommendations: First, minimum requirements on qualifications of an academic dean/director based on policies and standards of the Commission on Higher Education should be met before appointing him to the position; Second, an academic dean/director should attend conferences, seminar-workshops in order that he be kept abreast of the latest trends; continuing education will make her more knowledgeable and competent in the performance of his function. Third, faculty meetings should be strengthened such that they can be means of enhancing professional growth; Fourth, an academic dean/director should come out with a functional supervisory program and should closely follow it up; and last, an academic dean/director should be committed to the cause of quality education.
\end{abstract}

Keywords - Leadership, Academic Leadership, Leadership Skills, Institutional Leaders, Higher Education.

\section{INTRODUCTION}

Leadership has the power to create, sustain, and destroy an organization. It is the key to effective management. Significant improvements were reported on all constructs of leadership, even when the participants saw themselves as already skilled (McDade et al., 2004). Nevertheless, the creation of leadership raises unique challenges, including a wide range of professional roles and complex operational centers that may impede the unity of a leadership team in service of a core mission (Korschun et al., 2007).

Strategic leadership skills are typically essential for organizational progress according to the perspective of strategic leadership, resource-based, and knowledge-based views of the groups (Mahdi \&Almsafir, 2014). Strong visible leadership is valued when it provides transparency and 
direction; but only when it helps to convey the institutional members ' collective interests (Bolden et al., 2009).

In making decisions involving any of the stakeholders, an academic leader will consider the impact of a decision on improving loyalty, support, cooperation, good union ties and smooth interactions with administrative departments (Rowley \& Sherman, 2003).It is expected that academic leaders will not only handle their area of responsibility well, but will also know how to build the ability of their department and university to continuously evaluate and improve performance (Anderson et al., 2008).

Upon this premise, the researchers postulate that desirable qualities of academic deans are essential catalyzes of this instructors teaching performance.

\section{CONCEPTUAL FRAMEWORK}

Institutions should advance in recognizing the value of identifying and training leaders for the success of their missions, as a shift is needed in most cultures of higher education to value and reward good leadership (Bisbee, 2007).

In line with the duties and responsibilities of these program directors, a successful director must also possess leadership skills crucial to the evolving academic environment are multiple and highly diversified (Bordage et al., 2000).

The most influential role is the ability to effectively implement initiatives, enhance the institution's recognition and reputation, and achieve personal and interpersonal outcomes, while focusing on learning and teaching successes and financial performance results shape perceptions of effective leadership capabilities slightly less (Scott et al., 2008).

Table 1. NEUST Campus Directors / College Deans' Perceptions of Their Leadership

Capabilities

\begin{tabular}{|l|l|l|l|l|l|}
\hline Leadership Aspect & $\begin{array}{l}\text { Satellite } \\
\text { Campuses } \\
(\mathbf{n = 4})\end{array}$ & $\begin{array}{l}\text { Main } \\
\text { Campus } \\
(\mathbf{n = ~ 6 )}\end{array}$ & $\begin{array}{l}\text { Sumacab } \\
\text { Campus } \\
(\mathbf{n =} \text { 4) }\end{array}$ & $\begin{array}{l}\text { Weighted } \\
\text { Mean }\end{array}$ & $\begin{array}{l}\text { Std. } \\
\text { Deviation }\end{array}$ \\
\hline Job Knowledge and Management Skills & 4.56 & 4.32 & 4.45 & 4.42 & 0.3273 \\
\hline Language Communication & 4.65 & 4.50 & 4.40 & 4.51 & 0.4130 \\
\hline Cultural and Professional Growth & 4.54 & 4.54 & 4.79 & 4.59 & 0.3901 \\
\hline Personal and Social Qualities & 4.66 & 4.60 & 4.62 & 4.63 & 0.3065 \\
\hline
\end{tabular}

\section{OBJECTIVE OF THE STUDY}

The study describedthe perception of NEUST Campus Directors, College Deans and instructors towards their leadership capabilities in terms of job knowledge and managements skills, language communication, cultural and professional growth and personal and social qualities, and differences between NEUST Campuses directors' / deans' and instructors' perceptions.

\section{METHODOLOGY}

The descriptive method of research was used in this study because it involves description, recording, analysis and interpretation of condition that really exists (Creswell, 2014). The questionnaire is the main tool in gathering of data. A total of 103 respondents composing of 15 academic deans/directors and 88 college faculty in the 5 campuses of NEUST were surveyed. Mean, Weighted Mean, Standard deviation and t-test were used to analyze the gathered data.

\section{RESULTS AND DISCUSSION}

Table 1 shows the perceptions of directors and college deans in all the NEUST campuses on their leadership capabilities. Results reveal that the most outstanding leadership capability rated by the deans themselves was on personal and social qualities $(M=4.63, S D=0.3065)$. It could be deduced that all the deans have harmonious relationship with their instructors. It is indeed necessary for leaders to interact with the group which they participate and demonstrate their capacity to assist the groups to complete its task. With respect to language communication and cultural and professional growth, the deans rated themselves uniformly high ratings with means $4.51(S D=0.4130)$ and $4.59(S D=$ 0.3901) respectively. The least outstanding given was on job knowledge and communication skills. Data show that among all the leadership capabilities, the managerial function was given the least concern. 
Table 2. Instructors' perceptions of their director / dean leadership capabilities

\begin{tabular}{|c|c|c|c|c|c|}
\hline Leadership Aspect & $\begin{array}{c}\text { Satellite } \\
\text { Campuses } \\
(\mathrm{n}=50)\end{array}$ & $\begin{array}{c}\text { Main Campus } \\
(\mathrm{n}=70)\end{array}$ & $\begin{array}{c}\text { Sumacab } \\
\text { Campus } \\
(\mathrm{n}=56)\end{array}$ & $\begin{array}{c}\text { Weighted } \\
\text { Mean }\end{array}$ & Std. Deviation \\
\hline $\begin{array}{c}\text { Job Knowledge and } \\
\text { Management Skills }\end{array}$ & 4.22 & 3.55 & 4.16 & 3.93 & 0.8038 \\
\hline $\begin{array}{c}\text { Language } \\
\text { Communication }\end{array}$ & 4.34 & 3.66 & 4.16 & 4.01 & 0.7914 \\
\hline $\begin{array}{c}\text { Cultural and } \\
\text { Professional Growth }\end{array}$ & 4.30 & 3.57 & 4.18 & 3.97 & 0.7728 \\
\hline $\begin{array}{c}\text { Personal and Social } \\
\text { Qualities }\end{array}$ & 4.48 & 3.85 & 4.26 & 4.16 & 0.7020 \\
\hline
\end{tabular}

Table 2 reveals the instructors' perceptions of their deans'/directors' leadership capabilities in all three campuses. Statistics show that the leadership capability that garnered the highest rating was on personal and social qualities $(M=$ 4.16, $S D=0.7020)$. It can be implied that the teachers' relationship with their deans/directors is very satisfactory. A harmonious atmosphere prevails in the institution. The least rating was given to job knowledge and management skills ( $M$ $=3.97, S D=0.8038$ ). The condition implies that there are some deans/directors who are perceived by the instructors as not efficient on this aspect. It should be noted that employees prefer leaders who get results. Martinez (2000) postulates that if the organization succeeds, the leader gains the respect of his followers. If he fails, they will never fully respect him.

Table 3. T-test difference between NEUST Campuses directors' / deans' and instructors 'perceptions on leadership capabilities of the former

\begin{tabular}{|c|c|c|c|c|c|c|c|c|c|}
\hline $\begin{array}{c}\text { Leadership } \\
\text { Aspect }\end{array}$ & \multicolumn{2}{|c|}{ Satellite Campuses } & \multicolumn{2}{|c|}{ Main Campus } & \multicolumn{2}{c|}{ Sumacab Campus } & \multicolumn{2}{c|}{ Weighted Mean } & t-value \\
\hline & $\begin{array}{c}\text { Directors } \\
/ \text { Deans } \\
(n=4)\end{array}$ & $\begin{array}{c}\text { Instructors } \\
(n=50)\end{array}$ & $\begin{array}{c}\text { Directors } \\
/ \text { Deans } \\
(n=6)\end{array}$ & Instructors & $\begin{array}{c}\text { Directors } \\
/ \text { Deans } \\
(n=4)\end{array}$ & $\begin{array}{c}\text { Instructors } \\
(n=56)\end{array}$ & $\begin{array}{c}\text { Directors } \\
/ \text { Deans } \\
(n=14)\end{array}$ & $\begin{array}{c}\text { Instructors } \\
(n=176)\end{array}$ & \\
\hline $\begin{array}{c}\text { Job Knowledge } \\
\text { and Management } \\
\text { Skills }\end{array}$ & 4.55 & 4.22 & 4.32 & 3.55 & 4.45 & 4.16 & $\mathbf{4 . 4 2}$ & $\mathbf{3 . 9 3}$ & $\mathbf{2 . 2 4 1 *}$ \\
\hline $\begin{array}{c}\text { Language } \\
\text { Communication }\end{array}$ & 4.65 & 4.34 & 4.50 & 3.66 & 4.40 & 4.16 & $\mathbf{4 . 5 1}$ & $\mathbf{4 . 0 1}$ & $\mathbf{2 . 3 1 8 ^ { * }}$ \\
\hline $\begin{array}{c}\text { Cultural and } \\
\text { Professional } \\
\text { Growth }\end{array}$ & 4.54 & 4.30 & 4.49 & 3.57 & 4.79 & 4.18 & $\mathbf{4 . 5 9}$ & $\mathbf{3 . 9 7}$ & $\mathbf{2 . 9 1 6 * *}$ \\
\hline $\begin{array}{c}\text { Personal and } \\
\text { Social } \\
\text { Qualities }\end{array}$ & 4.66 & 4.48 & 4.60 & 3.85 & 4.62 & 4.26 & $\mathbf{4 . 6 3}$ & $\mathbf{4 . 1 6}$ & $\mathbf{2 . 4 5 3 * *}$ \\
\hline
\end{tabular}

Table 3 presents the result of the test of significant difference between the scores on the directors/deans' and instructors' perceptions. Job knowledge and management skills $(t=2.241, p<.05))$ and language communication $(t=$ $2.318, p<.05)$ both show the score differences of the directors/deans' and instructors' perception on the leadership aspect. Likewise, differences were also seen on the cultural and professional growth $(t=2.916, p<.01)$ and personal and social qualities $(t=2.453, p<.01)$ as perceived leadership aspects.

The table clearly reveals that the deans gave a higher self-rating which spells the difference. Their self- 
evaluation scores ranged from 4.42 , to 4.63 while the instructors' ratings were as low as 3.93 to 4.16 . The inconsistency of ratings maybe due to the directors'/deans' high perceptions of their leadership capabilities. However, such concept was not reflected in their performance which led the instructors to give them low ratings.

\section{CONCLUSIONS AND RECOMMENDATIONS}

Based on the foregoing findings, the following conclusions were drawn: First, academic deans/directors have high regard among themselves to be outstanding in their leadership capabilities. This implies that they were confident enough in their leadership capabilities. Second, instructors perceived their deans/directors to be human relations oriented. They cultivated the values of openness, fairness and approachability. Instructors feel comfortable with the "selfassurance" that their administrators were very much concerned of their welfare, personally and professionally. And last, there was incompatibility between deans'/directors self-perception and instructors' perception in the formers leadership capabilities. There were differences in the ratings of the two groups. Deans/Directors rated themselves good performers. The difference, though, is spatial rather than dimensional. In other words, the qualities that leaders possessed were perceived by both deans and instructors along a similar scale, although the measures varied.

In lieu of the stated conclusions, the researchers came up with the following recommendations: First, minimum requirements on qualifications of an academic dean/director based on policies and standards of the Commission on Higher Education should be met before appointing him to the position; Second, an academic dean/director should attend conferences, seminar-workshops in order that he be kept abreast of the latest trends; continuing education will make her more knowledgeable and competent in the performance of his function. Third, faculty meetings should be strengthened such that they can be means of enhancing professional growth; Fourth, an academic dean/director should come out with a functional supervisory program and should closely follow it up; and last, an academic dean/director should be committed to the cause of quality education.

\section{REFERENCES}

[1] Anderson, M., Scott, G., \& Coates, H. (2008). A tight balancing act: Leadership challenges for University Heads.
[2] Bisbee, D. C. (2007). Looking for leaders: Current practices in leadership identification in higher education. Planning and Changing, 38, 77-88.

[3] Bolden, R., Petrov, G., \& Gosling, J. (2009). Distributed leadership in higher education: Rhetoric and reality. Educational Management Administration \& Leadership, 37(2), 257-277. https://doi.org/10.1177/1741143208100301

[4] Bordage, G., Foley, R., \&Goldyn, S. (2000). Skills and attributes of directors of educational programmes. MEDICAL EDUCATION-OXFORD-, 34(3), 206-210. https://doi.org/10.1046/j.1365-2923.2000.00425.x

[5] Creswell, J. W. (2014). A concise introduction to mixed methods research. SAGE publications.

[6] Mahdi, O. R., \&Almsafir, M. K. (2014). The role of strategic leadership in building sustainable competitive advantage in the academic environment. Procedia-Social and Behavioral Sciences, 129, 289-296.

https://doi.org/10.1016/j.sbspro.2014.03.679

[7] McDade, S. A., Richman, R. C., Jackson, G. B., \& Morahan, P. S. (2004). Effects of participation in the Executive Leadership in Academic Medicine (ELAM) program on women faculty's perceived leadership capabilities. Academic Medicine, 79(4), 302-309. https://doi.org/10.1097/00001888-200404000-00005

[8] Rowley, D. J., \& Sherman, H. (2003). The special challenges of academic leadership. Management Decision. https://doi.org/10.1108/00251740310509580

[9] Scott, G., Coates, H., \& Anderson, M. (2008). Learning leaders in times of change: Academic leadership capabilities for Australian higher education. 